\title{
Motivational Preferences of Employees in Requirements of Czech and Russian Transport and Logistics Enterprises
}

\author{
Lenka Ližbetinová \\ Institute of Technology and Business in \\ České Budějovice \\ Faculty of Corporate Strategy \\ Czech Republic \\ e-mail: lizbetinova@mail.vstecb.cz
}

\author{
Miloš Hitka \\ Technical University in Zvolen \\ Department of Enterprise Management \\ Slovak Republic \\ e-mail: hitka@tuzvo.sk
}

\author{
Mikhail Kleymenov \\ Ural State University of Economics \\ Applied Sociology Department \\ Russian Federation \\ e-mail:k-mihaell@mail.ru
}

\author{
DOI 10.17818/NM/2018/4SI.17 \\ UDK 331.101 .3 \\ 656:334.71 \\ Preliminary communication \\ Paper accepted: 28. 8. 2018.
}

\begin{abstract}
Summary
The aim of the paper is to identify the employees' groups based on the differences in their motivation preferences in the environment of transport and logistics enterprises in selected regions. Loyal, satisfied and efficient employees are a key success factor for service enterprises in general. This is due to the fact that service sphere is characterized by the low level of anonymity of the service provider, therefore the level of professional approach of employees in direct interaction becomes the most important in terms of customer satisfaction. The paper represents partial result of research aimed at the identification of motivational preferences of employees in the specific conditions of logistics enterprises. The research was carried out in the Czech Republic and Russian Federation (Sverdlovsk region) in 2017 and the research sample consisted of 571 and 860 respondents employed in transport and logistics enterprises. There is a proposed use of Cluster analysis method in the paper. The research results obtained can help better understand the motivational preferences of the transport and logistics staff and thus create the possibility of more efficient formulation of incentive programs.
\end{abstract}

\section{KEY WORDS}

motivation motivational factors transport and logistics enterprises transport and logistics cluster analyses

\section{INTRODUCTION}

The dominant attribute of current logistics is the increase in the number and quality of links of the sub-links of the logistics chain [1], [2] on a global scale. As in other economy sectors, transport and logistics are dominated by the supply above the demand [3]. Enterprises increasingly look for new ways and means to enable them to succeed in a very competitive environment [4], [5]. This fact forces business entities to use not only innovative technologies but also to seekquality human resources [6], [7].Because of globalization, there is an increasing expansion of the consumer market [8], [9] and consequently the expansion of the transport market. The need to bridge larger distances in the shortest possible time becomes the main requirement and criterion for customers, mainly due to the increased volume of product exports and mobility of persons [10-12]. The pressure is also put not only on the relocation of goods in precisely defined quantities and dates, at affordable prices and with minimal ecological burden on the environment, but also on adaptation to the specific individual needs of customers [13], [14]. The very strong qualitative personnel background [15] of the enterprises will help differentiate themselves from the competition by providing quality and fast transport and logistics services [16]. The specific nature of transport and logistics services has a direct impact on the assessment of the quality of work carried out by individual workers and on the possibility of assessing the quality of services by the consumer.

From the marketing point of view, there is a dominant demand for service provider flexibility at all levels of management, as well as at the level of employees who are directly involved in the service delivery process and come into direct contact with the customer [17-19]. Customer expectations and demands on the quality of work, and the level of professional approach to direct interaction from the point of view of customer satisfaction become crucial due to the low degree of anonymity of the service provider.

Many enterprises have a problem with a lack of quality human resources [20-23] and are looking for ways to solve this deficit. Another issue is how to maintain and motivate a quality workforce that has proven itself and is professionally trained [2325]. The answer is to find out how these workers have preferences and needs in the work relationship and what motivates them to perform better and what demotivates them.

\section{MATERIAL AND METHODS}

The aim of the paper is to identify the employees' groups based on the differences in their motivation preferences in the environment of transport and logistics enterprises in selected regions. The paper represents partial result of research aimed at the identification of motivational preferences of employees in the specific conditions of logistics enterprises. The research was carried out in the Czech Republic and Russian Federation (Sverdlovsk region) in 2017 and the research sample consisted of 571 (Czech) and 860 (Russian) respondents of transport and logistics enterprises. The respondents were chosen by a random choice method among the employees of transporting and 
logistic companies from both countries. The characteristics of respondents are in Table 1.

The research was conducted by means of an electronic questionnaire distributed among respondents. Within this research, respondents evaluated their preferences of 30 motivational factors on the Likert scale. The scales had a form of statements and respondents had the opportunity to express themselves in the range of five points: 1 meant unimportant, 2 slightly important, 3 - neutral, 4 - important, 5 - very important. Data were processed with the help of the SPSS [26] and their usefulness was tested by the Mann-Whitney U-test. K-Means Cluster Analysis was applied, as the procedure attempts to identify relatively homogeneous groups of cases based on selected characteristics, using an algorithm that can handle large number of cases [27].

Table 1 Characteristics of the respondents

\begin{tabular}{|c|c|c|c|}
\hline & & Czech Republic & Russian Federation \\
\hline & & $\begin{array}{l}\text { Number of } \\
\text { respondents }\end{array}$ & $\begin{array}{l}\text { Number of } \\
\text { respondents }\end{array}$ \\
\hline \multirow{2}{*}{$\frac{\bar{d}}{\frac{1}{c}}$} & Male & 240 & 379 \\
\hline & Female & 331 & 481 \\
\hline \multirow{5}{*}{ 家 } & less than 30 years & 186 & 352 \\
\hline & $31-40$ years & 151 & 175 \\
\hline & 41-50 years & 129 & 238 \\
\hline & over 50 years & 105 & 100 \\
\hline & Total & 571 & 860 \\
\hline
\end{tabular}

Source: authors

\section{RESULTS AND DISCUSSIONS}

The respondents' attitudes towards the above motivational factors are based on expressing their preferences on Linkert scale. Respondents of both regions reacted to these statements using an assessment scale of five levels. Using cluster method (k-means) the employee clusters were set up for Czech Republic and Sverdlovsk regions. These clusters will be introduced in a more detail below. Table 2 shows numbers of cases in these clusters.

Table 2 Frequencies of Czech and Russian clusters of employees in requirements of transport and logistics enterprises

\begin{tabular}{|c|c|c|c|}
\hline \multicolumn{4}{|c|}{ Czech Republic } \\
\hline & & Number of Cases in each Cluster & $\%$ \\
\hline \multirow{3}{*}{ Cluster } & 1 & 82.0 & 14.4 \\
\hline & 2 & 235.0 & 41.1 \\
\hline & 3 & 254.0 & 44.5 \\
\hline \multicolumn{2}{|l|}{ Valid } & 571.0 & 100.0 \\
\hline \multicolumn{2}{|l|}{ Missing } & 0.0 & \\
\hline \multicolumn{4}{|c|}{ Russian Federation - Sverdlovsk region } \\
\hline & & Number of Cases in each Cluster & $\%$ \\
\hline \multirow{3}{*}{ Cluster } & 1 & 21.0 & 2.5 \\
\hline & 2 & 346.0 & 40.2 \\
\hline & 3 & 493.0 & 57.3 \\
\hline \multicolumn{2}{|l|}{ Valid } & 860.0 & 100.0 \\
\hline \multicolumn{2}{|l|}{ Missing } & 0.0 & \\
\hline
\end{tabular}

Source: authors

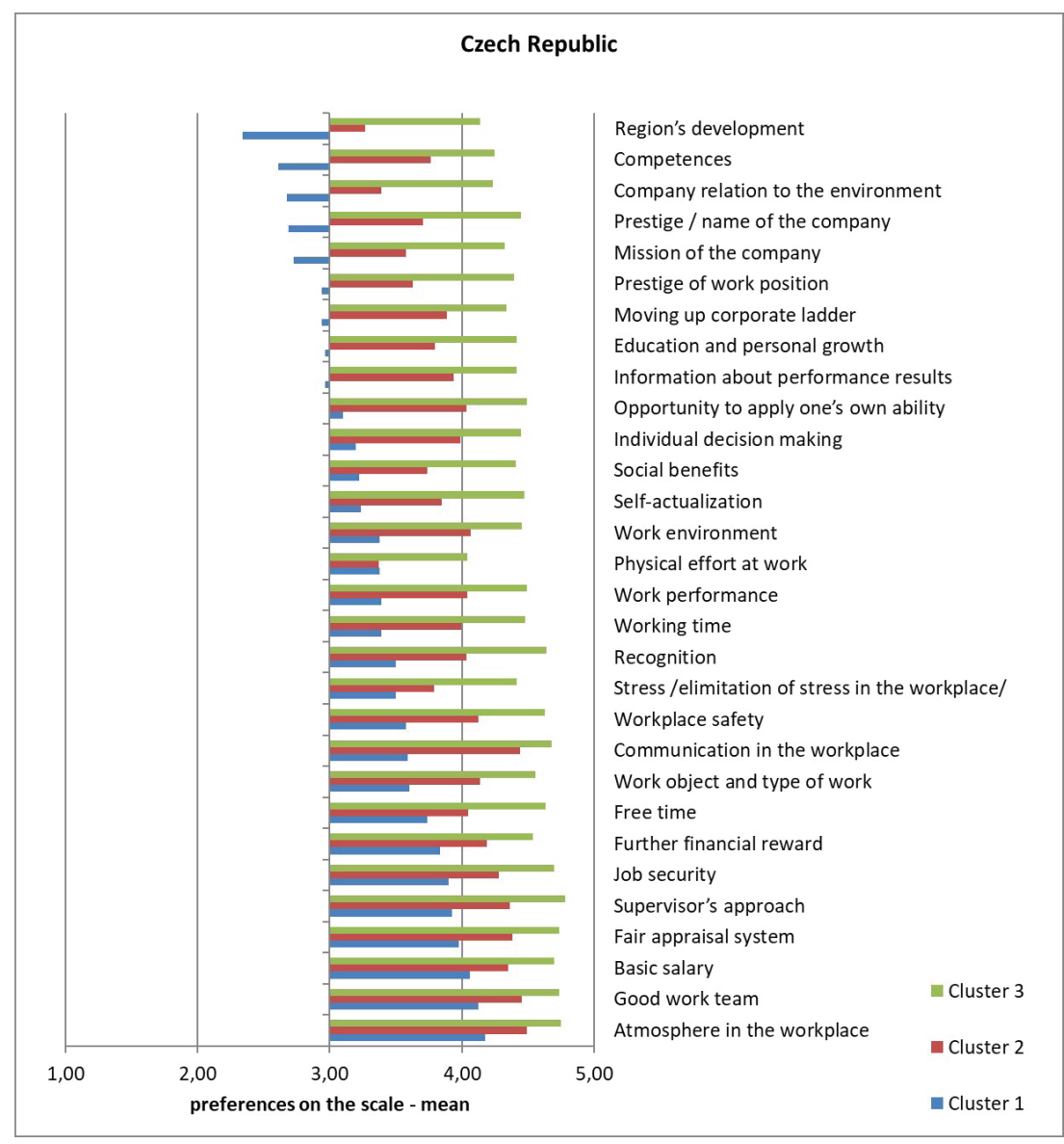

Source: authors

Figure 1 Motivational preferences of Czech cluster members 
Evaluating the preferences of the respondents, three clusters, whose members are from Czech transport and logistics enterprises - Czech Clusters 1, 2, and 3, were identified. On the other side, members belonging to Russian Clusters 1, 2, and 3 are employees of Sverdlovsk transport and logistics enterprises. Figure 1 shows the motivational preferences of employees from Czech Republic and Figure 2 from Russian Federation in Sverdlovsk region. The $x$ axis shows the final centres of clusters of the assessment of the importance of the motivation factor, where 1 is meaningless and 5 very important.

\subsection{Czech Cluster 1 - Flexible and less demanding}

This cluster represents the smallest group of employees, accounting for $14.4 \%$. Members of this cluster are relatively young employees with primary and lower secondary education. They hold mainly positions of blue-collar workers (49\%) and white-collar workers (30\%). Women represent $52 \%$ of this cluster, with the most disparate age category being women under 30 ( $46 \%$ of women and $27 \%$ of the total), and the lowest category is men over 50 (only 5\%). These employees with a work experience of up to 3 years are represented by $52 \%$.

This cluster is a less demanding group of employees, which does not require such a high level of motivational factors to be fulfilled as in other clusters. They consider important the work atmosphere and workplace collaboration within the team, but they are not as demanding as in the other two groups of employees of Czech Transport and Logistics Enterprises. Nonetheless, they rank the financial rankings at 3 in a row. This implies that they are able to adapt more flexibly to working time, labour conditions, work safety deficiencies under conditions of higher financial income. These employees need a serious approach to the superior, a fair job evaluation and job security. Career practices, the prestige of the employer and the prestige of the job are not very important to them (Table 3 and Figure 1).

\subsection{Czech Cluster 2 - Social interrelationships}

It represents $41.1 \%$ of employees. This is a gender-balanced group of employees ( $53 \%$ of men) and $60 \%$ of these employees are less than 40 years old. From the point of view of the educational structure, they are represented in all categories. These employees have a comparable share of managerial positions (35\%) and white-collar workers (34\%) and bluecollar workers. $45 \%$ of women work in the positions of whitecollar workers and $34 \%$ in post managers.

For this group of employees, the salary is 6th in the rankings (Table 3 and Figure 1). As with the Cluster 1, the atmosphere and workplace relationships are the prime factor for them. Their emphasis on social relations is underlined by the preference of adequate communication and of a serious attitude and approach by superiors. This group is more professionally oriented, they prefer the type and content of work and the actual work performance before career motivational factors.

\subsection{Czech Cluster 3 - Demanding}

This group is represented by $44.5 \%$ of employees. It is a gender-balanced group of employees (53\% of women) with men falling without significant age restrictions and women mostly under the age of 40 (59\% of women). $77 \%$ of women have higher secondary education (47\%) and higher education (30\%) and 56\% men are upper secondary educated. These practitioners have the most extensive length of practice of up to 1-3 years and over 10 years. $70 \%$ of employees work as managers (36\%) and white-collar workers (34\%).

Employees belonging to the 3rd group place emphasis first on a direct leader and subsequently on relationships at the workplace (Table 3 and Figure 1). Job security and consequently the salary rating are also very important to them. In this group, however, the preferences of the individual factors are balanced, and this is a more demanding group of employees who have higher demands in terms of the required level of the motivators. Their preference favours job security and enough free time for career advancement and prestige. It is a group of employees who want to rationalize their work and free time so that the earned money serves to enjoy life.

Table 3 Motivational factor preference in the Czech Republic by cluster

\begin{tabular}{|c|c|c|c|c|c|}
\hline \multicolumn{6}{|c|}{ Preference motivational factors of Czech clusters } \\
\hline \multicolumn{2}{|l|}{ Cluster 1} & \multicolumn{2}{|l|}{ Cluster 2} & \multicolumn{2}{|l|}{ Cluster 3} \\
\hline Atmosphere in the workplace & 4.18 & Atmosphere in the workplace & 4.49 & Supervisor's approach & 4.77 \\
\hline Good work team & 4.13 & Good work team & 4.45 & Atmosphere in the workplace & 4.75 \\
\hline Basic salary & 4.06 & Communication in the workplace & 4.43 & Good work team & 4.74 \\
\hline Fair appraisal system & 3.98 & Fair appraisal system & 4.38 & Fair appraisal system & 4.73 \\
\hline Supervisor's approach & 3.93 & Supervisor's approach & 4.36 & Job security & 4.70 \\
\hline Job security & 3.90 & Basic salary & 4.34 & Basic salary & 4.69 \\
\hline Further financial reward & 3.83 & Job security & 3.90 & Communication in the workplace & 3.58 \\
\hline Free time & 3.73 & Further financial reward & 3.83 & Recognition & 3.5 \\
\hline Work object and type of work & 3.60 & Work object and type of work & 3.6 & Free time & 3.73 \\
\hline Communication in the workplace & 3.58 & Workplace safety & 3.57 & Workplace safety & 3.57 \\
\hline
\end{tabular}

Source: authors 


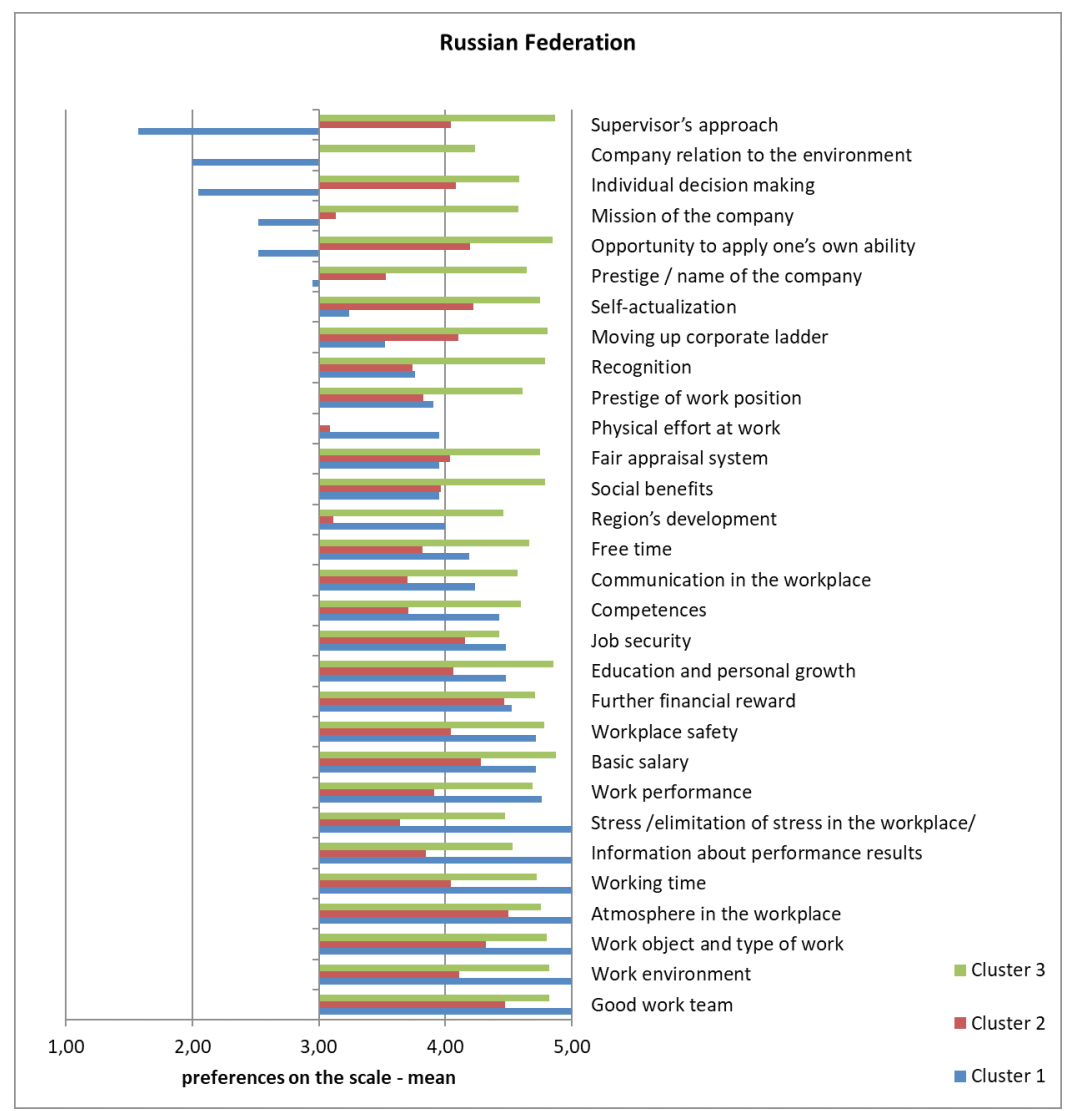

Source: authors

Figure 1 Motivational preferences of Russian cluster members

Table 3 Motivational factor preference in the Sverdlovsk region by cluster

\begin{tabular}{|c|c|c|c|c|c|}
\hline \multicolumn{6}{|c|}{ Preference motivational factors of Russian clusters } \\
\hline \multicolumn{2}{|l|}{ Cluster $1(2.5 \%)$} & \multicolumn{2}{|l|}{ Cluster 2 (40.2\%) } & \multicolumn{2}{|l|}{ Cluster $3(57 . \%)$} \\
\hline $\begin{array}{l}\text { Stress /elimitation of stress in the work- } \\
\text { place/ }\end{array}$ & 5.00 & Atmosphere in the workplace & 4.50 & Basic salary & 4.87 \\
\hline Working time & 5.00 & Good work team & 4.47 & Supervisor's approach & 4.87 \\
\hline Work environment & 5.00 & Further financial reward & 4.47 & Education and personal growth & 4.86 \\
\hline Good work team & 5.00 & Work object and type of work & 4.32 & Opportunity to apply one's own ability & 4.85 \\
\hline Work object and type of work & 5.00 & Basic salary & 4.28 & Work environment & 4.82 \\
\hline Information about performance results & 5.00 & Self-actualization & 4.22 & Good work team & 4.82 \\
\hline Atmosphere in the workplace & 5.00 & Opportunity to apply one's own ability & 4.19 & Moving up corporate ladder & 4.81 \\
\hline Work performance & 4.76 & Job security & 4.16 & Work object and type of work & 4.81 \\
\hline Basic salary & 4.71 & Work environment & 4.11 & Social benefits & 4.79 \\
\hline Workplace safety & 4.71 & Moving up corporate ladder & 4.10 & Recognition & 4.79 \\
\hline
\end{tabular}

Source: authors

\subsection{Russian Cluster 1 - Bohemians}

This is the smallest group within the clusters - $2.5 \%$, which is gender balanced. Employees are mostly of the age of 41 to 50 , mainly with university education (length of practice is over 10 years). Members of the cluster work on the managerial positions - $31 \%$ and white-collar workers - $54 \%$.

This group of workers is particularly demanding in terms and background in the performance of work. They rely on their expertise and focus. Highly evaluate the psychological impact of work on their lives - the level of stress, work atmosphere and work team and leisure. Since it is a group of workers who are aware of their qualities and expertise, it is assumed that their financial rating is at a relatively high level, so their motivator core salary is up to the 9 th place. Career motivational factors and supervisor's approach are the expense of working conditions and the type, difficulty and certainty of work suppressing to a lower level.

\subsection{Russian Cluster 2 - Balancing Realists}

This cluster has a $40.2 \%$ share of employees. Together $64 \%$ of men age-matched in all categories, predominant secondary education of both categories, practice under 6 years $63 \%$ and 
$30.2 \%$ over 10 years. These employees work mostly in positions $29.8 \%$ are managers and $43 \%$ are blue-collar workers.

This is a group of employees who prefer a social motivation factors (atmosphere and team), but also considers financial valuation and expertise as very important. Career prospects and self-realization are important for this group. These employees have lower levels of motivational factors compared to other Russian figures. Preference for salary levels after basic social motivators - workplace atmosphere and teamwork.

\subsection{Russian Cluster 3 - Educated Young Careerists}

This group of employees is represented by $57.3 \%$ and is made up of $60 \%$ of women. Women predominantly of the younger age range are $39 \%$ under 30 , university and higher secondary education. They work in positions of managers (37\%) and whitecollar workers (39\%).

This group puts the financial valuation first and focuses its attention on the career factors as an application of their own capabilities, further education and career advancement. Selfrealization and the possibility of personal growth (education) are important to them. In addition to their expertise, attention is paid to the work environment and good teamwork.

\section{CONCLUSION}

The aim of the paper is to identify the employees' groups based on the differences in their motivation preferences in the environment of transport and logistics companies and their comparison in the selected regions. Based on the cluster analysis, three basic groups of participants were determined for the group of employees of transport and logistics companies according to their preferences for motivation factors. These groups are more closely characterized, and based on the comparison between the two countries, it is possible to state that in Russia employees place more emphasis on the career factors than the Czech ones. For both countries, a group is determined for which the amount of the financial evaluation is higher than that of other members of the labour market, as well as employees who focus mainly on social background and job security. Very important is the fact that Czech employees are also aware of the importance of free time. For the most demanding Russian group, leisure is also the important factor. In the case of Russian groups, it can be said that they have higher career preferences for motivation factors than the cluster in the Czech Republic. Knowing employee preferences is key not only to meet their needs but also to the targeted and rationally set incentive system where less costly measures can be used that will have a higher end-result in the form of satisfied, efficient and loyal employees.

\section{Acknowledgements}

This research was supported byVEGA 1/0024/17 and APVV-16- 0297.

\section{REFERENCES}

[1] Šulgan, M. Logistics park development in Slovak republic, Transport, 2006, Vol. 21, No. 3, pp.197-200. ISSN 1648-4142.

[2] Gnap, J, Rovňaníková, D., Rakovanová, R., Dvoryadkina, E.B. The Problems of Planning a Timetable for Transport by Road in Terms of Theft Protection. LOG - Scientific Journal on Transport and Logistics, 2017, Vol. 8, No. 1, pp.28-37. https://doi.org/10.1515/logi-2017-0004

[3] Kampf, R., Gašparík, J., Kudláčková, N. Application of different forms of transport in relation to the process of transport user value creation. Periodica Polytechnica Transportation Engineering, 2012, Vol. 40, No. 2, pp. 71-75. ISSN 0303-7800.
[4] Nadányiová, M. Greenwashing and its Impact on Slovak Consumers. Littera Scripta, 2016, Vol. 2, Issue 2, pp. 68-78. ISSN 1805-9112.

[5] Štarchoň, P., Weberová, D., Gender and attitudes of consumers towards the brand Slovak. Marketing Science and Inspirations, Vol. 9, No. 4, pp. 36-42.

[6] Hitka M., Lejsková P. Increasing efficiency of enterprise management employees' careers. 1st ed., 2015, České Budějovice: VŠTE v ČB, Czech Republic, $114 \mathrm{p}$.

[7] Olexova, C., Mesaros, P., Basistovs, A. Priorities of human resources management in knowledge economy. Business Trends - scientific periodic of Faculty of economic ZČU in Plzen, 2011, Vol. 1, pp. 26-30.

[8] Štarchoň, P. et al., Brands and Czech customer. 1st ed., 2015, Zlín: VeRBuM. Czech Republic, 104p.

[9] Kmecová, I. Business as Orientation Value for Developing the Spirit of Enterprise. Education Excellence and Innovation Management through Vision 2020: From Regional Development Sustainability to Global Economic Growth. Proceedings of the International Business Information Management Association (29 IBIMA), 2017, Vienna, Austria, pp. 2200-2209. ISBN 978-09860419-7-6.

[10] Kucharcíková, A., Tokarcíková, E., Klucka, J., Konušíková, J. Foreign direct investment: Impact on sustainable development in regions of Slovak Republic. Journal of Security and Sustainability, 2015, Vol. 5, No. 1, pp. 59-71. https://doi.org/10.9770/jssi.2015.5.1(5)

[11] Stachová, K., Stacho, Z. Competitiveness is based on human resources. 1st ed., 2014, Częstochowa: The Managers of Quality and Production Association, $135 \mathrm{p}$.

[12] Tokarčíková, E., Kucharčíková, A. Diffusion of innovation: The case of the Slovak mobile communication market. International Journal of Innovation and Learning, 2015, Vol. 17, No. 3, pp. 359-370. ISSN 1471-8197.

[13] Stopka, O., Bartuška, L., Kampf, R. Passengers' evaluation of the integrated transport systems. Nase More, 2015, Vol. 62, Special issue, pp.153-157. ISSN 1848-6320.

[14] Bartuška, L., Jeřábek, K., Li, C. Determination of traffic patterns on urban roads. Communications - Scientific Letters of the University of Zilina, 2017, Vol. 19, No. 2, pp. 103-108. ISSN 1335-4205.

[15] Farkašová, V., Rolková, M. Managerial roles in the current business environment. In: Globalization and its socio-economic consequences '13 refereed proceedings of the international conference. University of Žilina, 2013, Rajecké Teplice, Slovak Republic, pp. 121-128.

[16] Ližbetin, J., Caha, Z. The optimization of the intermodal terminals. Naše More, 2015, Vol. 62, Special Issue: pp. 97-100. ISSN 1848-6320.

[17] Kampf, R., Hitka, M., Potkány, M. Interannual differences in employee motivation in manufacturing enterprises in Slovakia. University of Zilina. Communications, 2014, Vol. 16, No. 4, pp. 98-102. ISSN 1335-4205.

[18] Lorincová, S., Schmidtová, J., Balážová, Ž. Perception of the corporate culture by managers and blue collar workers in Slovak wood-processing businesses. Acta Facultatis Xylologiae, 2016, Vol. 58, No. 2, pp. 149-163. ISSN 1336-3824.

[19] Mura, L., Horvath, P. Some aspects of human resource management. International Multidisciplinary Scientific Conferences on Social Sciences and Arts, 2015, Albena, Bulgaria, pp. 863-870.

[20] Urbancová, H., Hudáková, M. Employee development in small and medium enterprises in the light of demographic evolution. Acta Universitatis Agriculturae et Silviculturae Mendelianae Brunensis, 2015, Vol. 63, No. 3, pp. 1043-1050. ISSN 2464-8310

[21] Hockicko, P., Kristak, L., Nemec, M. Development of students' conceptual thinking by means of video analysis and interactive simulations at technical universities. European Journal of Engineering Education, 2015, Vol. 40, No. 2 , pp. 145-166. ISSN: 1469-5898

[22] Lorincová, S., Potkány, M. The proposal of innovation support in small and medium-sized enterprises. In Production Management and Engineering Sciences - Scientific Publication of the International Conference on Engineering Science and Production Management (ESPM 2015), 2015, Tatranska Strba, Slovak Republic, pp. 157-162.

[23] Lorincová, S., Schmidtová, J., Javorčíková, J. Employee Job Satisfaction in Furniture Manufacturing Companies in the Slovak Republic. Drvna Industrija, 2016, Vol. 67, No. 4, pp. 351-362. ISSN 1847-1153.

[24] Olšovská, A., Mura, L., Švec, M. Personnel management in Slovakia: An explanation of the latent issues. Polish Journal of Management Studies, 2016, Vol. 13, No. 2, pp. 110-120. ISSN 2081-7452.

[25] Hrmo, R., Kristofiakova, L., Kučerka, D. Developing the Information Competencies via E-learning and Assessing the Qualities of E-learning Text. Conference: 15th International Conference on Interactive Collaborative Learning (ICL), 2015, Villach, Austria, pp. 1-4. https://doi.org/10.1109/ ICL.2012.6402065

[26] IBM Corporation. K-Means Cluster Analysis. [Online], 2011, https://www. $\mathrm{ibm}$. com/support/knowledgecenter/SSLVMB_20.0.0/com.ibm.spss.statistics. help/idh_qui.

[27] IBM Corporation. IBM SPSS Statistics Standard (data analysis software system). [Online], 2016, http://www-01.ibm.com/software/analytics/spss/ products/statistics/. 